\title{
Cobalt-doped Hollow Carbon Framework as Sulfur Host for the Cathode of Lithium Sulfur Battery
}

\author{
JIN Gaoyao, HE Haichuan, WU Jie, ZHANG Mengyuan, LI Yajuan, LIU Younian
}

(Hunan Provincial Key Laboratory of Micro \& Nano Materials Interface Science, College of Chemistry and Chemical Engineering, Central South University, Changsha 410083, China)

\begin{abstract}
Lithium-sulfur batteries are deemed to be the next generation of cost-effective and high energy density systems for energy storage. However, low conductivity of active materials, shuttle effect and sluggish kinetics of redox reaction lead to serious capacity fading and poor rate performance. Herein, a sodium citrate derived three-dimensional hollow carbon framework embedded with cobalt nanoparticles is designed as the host for sulfur cathode. The introduced cobalt nanoparticles can effectively adsorb the polysulfides, enhance the kinetics of conversion reaction and further improve the cyclic and rate performance. The obtained cathode delivered a high initial discharge capacity of $1280 \mathrm{mAh} \cdot \mathrm{g}^{-1}$ at $0.5 C$, excellent high-rate performance up to $10 C$ and stable cyclic capacity of $770 \mathrm{mAh} \cdot \mathrm{g}^{-1}$ at $1 C$ for 200 cycles with high Columbic efficiency.
\end{abstract}

Key words: lithium sulfur battery; cobalt nanoparticle; conversion reaction; sulfur cathode

The lithium-sulfur (Li-S) batteries contain elemental sulfur, which possesses the superiorities of natural abundance, low $\operatorname{cost}^{[1]}$, and high specific capacity $\left(1672 \mathrm{mAh} \cdot \mathrm{g}^{-1}\right)^{[2]}$. However, the poor performance due to the low electrical conductivity of elemental sulfur $\left(5 \times 10^{-30} \mathrm{~S} \cdot \mathrm{cm}^{-1}\right)$, "shuttle effect" caused by dissolution of polysulfides and large volume expansion ( $~ 80 \%)$ during cycling seriously hinders the development of Li-S batteries $^{[3]}$. Vigorous studies have been devoted to the aforementioned issues, while cathode designing forms the largest class to date ${ }^{[4-5]}$. Previous work focused on encapsulating sulfur cathode into light host with excellent electronic conductivity, robust framework structure and enough pore volume ${ }^{[6-7]}$. Though carbonaceous materials can satisfy the criteria of cathode substrates, the forces between the nonpolar host and polar lithium polysulfides species (hereafter denoted as LiPSs) can be too weak ${ }^{[8]}$. The polar LiPSs species gradually diffuse during longterm cycling due to the single physical confinement. To increase the polarity of barrier skeletons, heteroatoms ${ }^{[9-10]}$ were introduced into the carbon host to produce stronger interaction with the LiPSs. These dopants can effectively capture the soluble polysulfide and restrain the shuttling effect.
Although the cathode performance can be improved to some extent with the synergy of heteroatoms and carbon framework, it is still significantly limited by the sluggish kinetics of polysulfide conversion reaction, which causes the excessive accumulation of LiPSs and inevitable diffusion $^{[11]}$. Transition metal compounds have been widely introduced into the sulfur host to accelerate the kinetics of conversion reaction ${ }^{[12-13]}$. In recent years, specific metal nanoparticles, such as $\mathrm{Co}^{[14]}, \mathrm{Fe}^{[15]}$ and $\mathrm{Pt}^{[16]}$, showed similar accelerating effect. Among these metals, cobalt metal has attracted the attention of researchers for its excellent conductivity and strong interaction with polysulfides. During the charging and discharging process, it can effectively capture the polysulfides and promote the conversion reaction ${ }^{[17-18]}$. Li, et al ${ }^{[19]}$ obtained the Co- and N-doped carbon as the sulfur host by the calcination of ZIF-67 precursor. The uniformly dispersed Co nanoparticles distinctly accelerated the redox reaction with the synergic effect of N-doped groups. Furthermore, $\mathrm{Du}$, et $a l{ }^{[20]}$ presented the monodisperse cobalt atoms embedded nitrogen-doped graphene cathode, and $\mathrm{Wu}$, et al. ${ }^{[21]}$ fabricated $\mathrm{Co}$ nanodots/N-doped mesoporous carbon with the in-situ calcination of adenine and $\mathrm{CoCl}_{2}$. In all of these reports, the Co-contained systems gained

Received date: 2020-03-27; Revised date: 2020-05-19; Published online: 2020-06-09

Foundation item: National Natural Science Foundation of China(21676304); Hunan Provincial Science and Technology Plan Project (2019TP1001)

Biography: JIN Gaoyao(1995-), male, Master candidate. E-mail: jingaoyao@csu.edu.cn 金高尧(1995-), 男, 硕士研究生. E-mail: jingaoyao@csu.edu.cn

Corresponding author: LI Yajuan, professor. E-mail: yajuanli@csu.edu.cn 李亚娟，教授. E-mail: yajuanli@csu.edu.cn 
excellent cycling performances.

In this work, to improve the cyclic and rate performance of Li-S batteries, a 3D hollow carbon framework decorated with cobalt nanoparticles was designed as the host of sulfur cathode. Sodium citrate, a cheap and plentiful additive, is employed as the carbon source for its unique character during direct calcination. And the electrochemical performance of the cobalt-containing system (Co/C-700) and carbon framework (HEC-700) was systematically evaluated to ensure the effect of doped cobalt nanoparticles for the sulfur cathode.

\section{Experimental}

\subsection{Synthesis of materials}

All chemical reagents used in this work were of analytical grade without further purification. Briefly, $0.25 \mathrm{~g} \mathrm{Co}\left(\mathrm{NO}_{3}\right)_{2} \cdot 6 \mathrm{H}_{2} \mathrm{O}$ and $5.0 \mathrm{~g}$ sodium citrate were dissolved in $20 \mathrm{~mL}$ deionized water under magnetic stirring to form a homogeneous solution. Then, the solution was freeze-dried, ground into fine powder and calcined at $700{ }^{\circ} \mathrm{C}$ under $\mathrm{N}_{2}$ for $1 \mathrm{~h}$ with a heating rate of $5{ }^{\circ} \mathrm{C} \cdot \mathrm{min}^{-1}$. The obtained composites (named as UWC700) were washed with deionized water for 3 times in order to remove the by-products. After being dried at $60{ }^{\circ} \mathrm{C}$ overnight, the final product was collected and denoted as $\mathrm{Co} / \mathrm{C}-700$. To further confirm the effect of $\mathrm{Co}$, hydrochloric acid etched carbon (HEC-700) was obtained by etching $\mathrm{Co} / \mathrm{C}-700$ in $2 \mathrm{~mol} / \mathrm{L} \mathrm{HCl}$ for $12 \mathrm{~h}$, washing until neutral and drying at $80{ }^{\circ} \mathrm{C}$ for $12 \mathrm{~h}$.

The cathode composites were prepared via a conventional melting-diffusion method. In brief, a mixture of sulfur (70wt\%) and Co/C-700 (or HEC-700) composites were milled for $20 \mathrm{~min}$, transferred into a $20 \mathrm{~mL}$ Teflon container autoclave and heated at $155{ }^{\circ} \mathrm{C}$ for $12 \mathrm{~h}$. The obtained powder was collected as $\mathrm{S} @ \mathrm{Co} / \mathrm{C}-700$ and S@HEC-700.

The materials characterization and static adsorption of polysulfides are shown in supporting materials.

\subsection{Electrochemical characterization}

The electrochemical performance of the S@Co/C-700 and S@HEC-700 cathodes were tested by CR2025 type coin cells, fabricated in an argon-filled glove box (MBraun, Germany). The sulfur cathode slurry was prepared by mixing S@Co/C-700 (or S@HEC-700), acetylene black and polyvinylidene difluoride (PVDF) binder with a weight ratio of $7: 2: 1$ in $N$-methyl-2pyrrolidinone (NMP). Then the obtained slurry was uniformly casted onto an Al foil. Furthermore, the membrane was dried at $50{ }^{\circ} \mathrm{C}$ under vacuum overnight and cut into discs ( $1 \mathrm{~cm}$ in diameter) with a sulfur loading of
$1.1-1.7 \mathrm{mg} \cdot \mathrm{cm}^{-2}$. The routine polypropylene membrane (Celgard 2400) was used to separate the cathode and lithium anode. The electrolyte used in each cell was $50 \mu \mathrm{L} 1 \mathrm{~mol} / \mathrm{L} \mathrm{LiN}\left(\mathrm{CF}_{3} \mathrm{SO}_{2}\right)_{2}$ and $1 \mathrm{wt} \% \mathrm{LiNO}_{3}$ solution in DOL/DME (1:1 in volume). Galvanostatic chargedischarge tests were performed by a LAND CT 2001A battery test system (Jinnuo Electronic Co, Wuhan, China) within the voltage window of $1.7-2.8 \mathrm{~V}$. The cyclic voltammetry $(\mathrm{CV})$ measurement was performed from 1.5 to $3.0 \mathrm{~V}$ at a scan rate of $0.1 \mathrm{mV} \cdot \mathrm{s}^{-1}$. Electrochemical impedance spectroscopy (EIS) was carried out in the frequency range from $0.1 \mathrm{MHz}$ to $10 \mathrm{mHz}$ with a voltage amplitude of $5 \mathrm{mV}$ at open-circuit. The $\mathrm{CV}$ and EIS measurements were carried out on a CHI 660E electrochemical Workstation (Chenhua Instruments Co, Shanghai, China). The symmetrical cells were assembled with $\mathrm{Co} / \mathrm{C}-700$ or HEC-700 (8:2 with PVDF in weight ratio) as identical cathode and anode, and $50 \mu \mathrm{L}$ electrolyte of $1 \mathrm{~mol} / \mathrm{L} \mathrm{LiN}\left(\mathrm{CF}_{3} \mathrm{SO}_{2}\right)_{2}, 1 \mathrm{wt} \% \mathrm{LiNO}_{3}$ and $0.2 \mathrm{~mol} / \mathrm{L} \mathrm{Li}_{2} \mathrm{~S}_{6}$ in DOL/DME(1:1 in volume) solution.

\section{Results and discussion}

Fig. 1 shows the schematic illustration of the synthetic procedure for three-dimensional (3D) cobalt doped carbon composite. When sodium citrate (SC) was annealed in inert atmosphere, the $\mathrm{Na}^{+}$species transformed into $\mathrm{Na}_{2} \mathrm{CO}_{3}$ crystals while ultrathin carbon nanosheets appeared on the surface ${ }^{[22]}$. With the temperature further increasing, the crystals act as activating agent and react with the coated carbon to form the straticulate porous shells ${ }^{[23]}$. Meanwhile, cobalt elements were transformed into Co nanoparticles and embedded on carbon framework with the carbon thermal reduction.

The composition and crystal structure of UWC-700 and $\mathrm{Co} / \mathrm{C}-700$ were characterized by XRD. The main diffraction peaks of UWC-700 (Fig. S1) are consistent with monoclinic $\mathrm{Na}_{2} \mathrm{CO}_{3}$ (PDF\#72-0628), while other

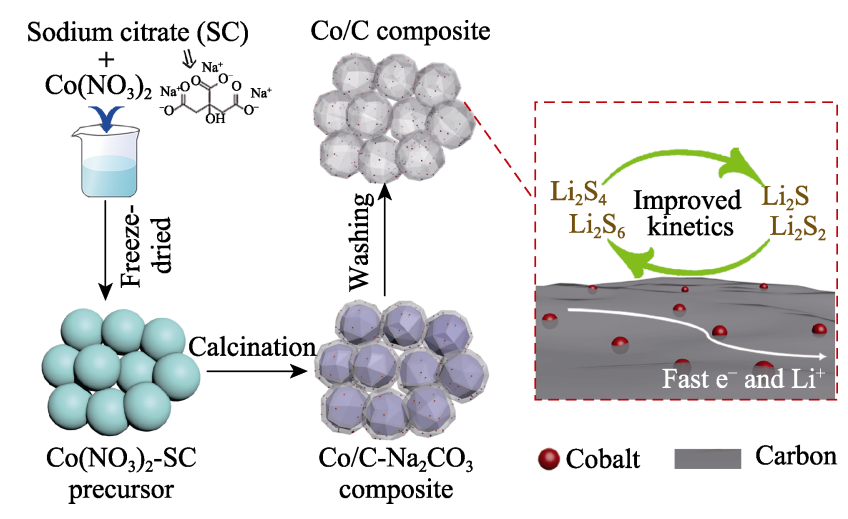

Fig. 1 Schematic illustration for the synthesis steps of hollow $\mathrm{Co} / \mathrm{C}$ composite and its effect for the resulting electrode 
three peaks at $2 \theta=44.2^{\circ}, 51.5^{\circ}$ and $75.9^{\circ}$ fit well with crystalline data of Co (PDF\#15-0806), indicating the totally decomposition of SC and reduction of cobalt element. The XRD pattern of $\mathrm{Co} / \mathrm{C}-700$ (Fig. 2(a)) with only characteristic peaks of cobalt metal suggests the complete removal of $\mathrm{Na}_{2} \mathrm{CO}_{3}$. In addition, the obvious broad peak at around $2 \theta=26^{\circ}$ represents the (002) plane of the graphitized carbon ${ }^{[24-25]}$. Meanwhile, as shown in the Raman spectra (Fig. 2(b)) of $\mathrm{Co} / \mathrm{C}-700$, the intensity ratio for the two obvious bands of $\mathrm{D}\left(1382 \mathrm{~cm}^{-1}\right)$ and $\mathrm{G}\left(1594 \mathrm{~cm}^{-1}\right)$ is 0.866 , responding to its high graphitized degree. In addition, the small peak at $680 \mathrm{~cm}^{-1}$ is the characteristic peak of cobalt ${ }^{[26]}$. The TGA curve of Co/C-700 is shown in Fig. S2(a) to ensure the Co content. The final product $(17.83 \mathrm{wt} \%)$ after TGA test can be identified as $\mathrm{Co}_{3} \mathrm{O}_{4}$ (Fig. S2(b)), and the corresponding Co content in $\mathrm{Co} / \mathrm{C}-700$ is $13.09 \mathrm{wt} \%$ by calculation, which fits well with the XPS result (Fig. 2(c)), the atomic and weight ratios of Co are $3.24 \mathrm{at} \%$ and $13.66 \mathrm{wt} \%$, respectively.

The porous structure of $\mathrm{Co} / \mathrm{C}$ was characterized by BET methods. The $\mathrm{N}_{2}$ adsorption-desorption isotherm (Fig. 2(d)) shows a distinct hysteresis loop, representing the abundant mesoporous structure. The specific surface area value and pore volume were measured to be $376.13 \mathrm{~m}^{2} \cdot \mathrm{g}^{-1}$ and $0.52 \mathrm{~cm}^{3} \cdot \mathrm{g}^{-1}$, respectively. The pore size distribution (inset in Fig. 2(d)) determined by the Barrett-Joyner-Halenda (BJH) method shows a distinct hierarchically porous structure with high mesoporosity
(62.76\%, Table S1). The interconnected mesopore and high surface area can adequately expose the cobalt sites for adsorption and further enhancement of redox reaction. In addition, the same tests were performed with the other two samples, UWC-700 and HEC-700 (Fig. S3). The extremely low surface area $\left(15.09 \mathrm{~m}^{2} \cdot \mathrm{g}^{-1}\right)$ and pore volume $\left(0.026 \mathrm{~cm}^{3} \cdot \mathrm{g}^{-1}\right)$ of UWC-700 show that the majority of the pores are filled with the $\mathrm{Na}_{2} \mathrm{CO}_{3}$ crystals. The surface area and pore volume of HEC-700 are almost the same as $\mathrm{Co} / \mathrm{C}-700$, which mean the well preservation of carbon framework during the etching steps. In addition, the volume of mesopore in HEC-700 (Table S1) increased by $5.4 \%$ after etching, confirming that the Co nanoparticles were in mesoporous size.

The morphology and structure of $\mathrm{Co} / \mathrm{C}-700$ were characterized by SEM (Fig. S4) and TEM (Fig. 3(a, b)). The Co/C-700 particles show the structure of 3D interconnected carbon shell. The high-resolution TEM (HRTEM) image (Fig. 3(c)) further shows that the lattice fringes of the nanoparticle with a $d$-spacing of $0.205 \mathrm{~nm}$ corresponds to the (111) plane of metallic cobalt. The $d$-spacing of crooked fringes wrapping the nanoparticle $(0.35 \mathrm{~nm})$ is in good agreement with the (002) plane of graphitic carbon. The EDS mapping images (Fig. 3(d)) show the distribution of $\mathrm{Co}, \mathrm{C}$ and $\mathrm{O}$ elements, confirming that the cobalt element uniformly disperses on the carbon shells.

To further confirm the electrochemical effect of Co
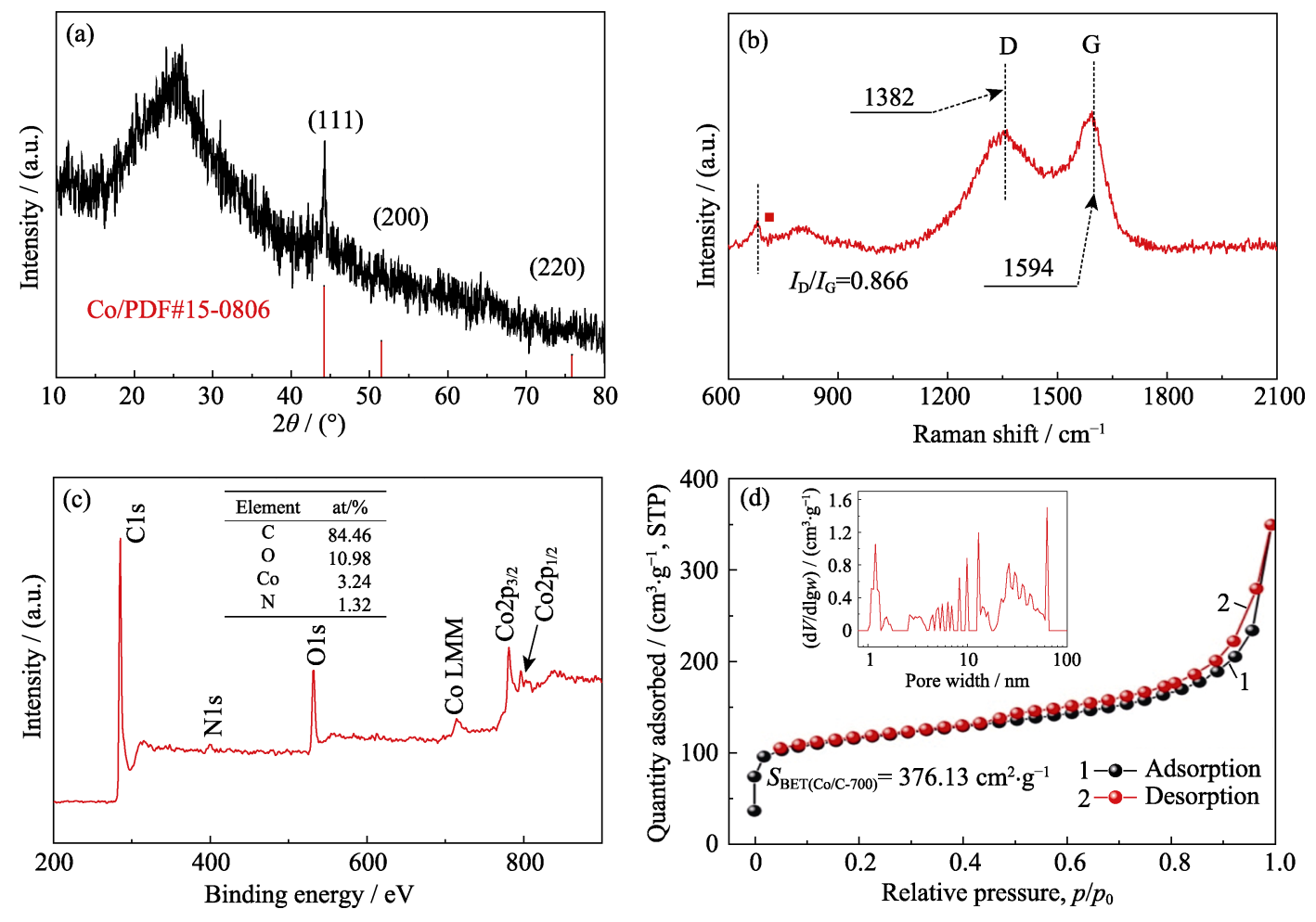

Fig. 2 (a) XRD pattern, (b) Raman spectrum, (c) XPS spectrum and (d) $\mathrm{N}_{2}$ adsorption/desorption isotherm of $\mathrm{Co} / \mathrm{C}-700$ with insert in (d) showing pore size distribution 

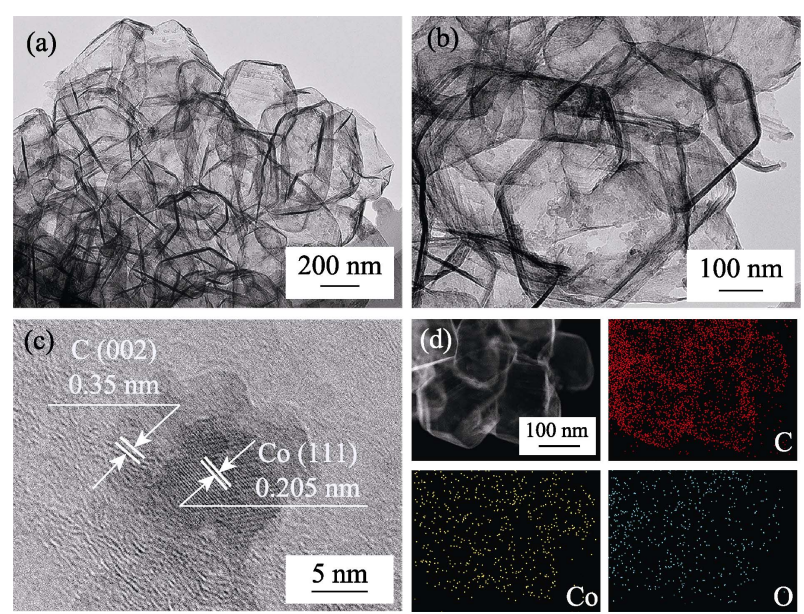

Fig. 3 (a, b) TEM, (c) high-resolution TEM (HRTEM) images and (d) EDS elemental mappings (Co, $\mathrm{C}$ and $\mathrm{O}$ ) of $\mathrm{Co} / \mathrm{C}-700$

nanoparticles in Li-S batteries, HEC-700 was employed as the control sample. The XRD pattern, SEM image (Fig. S5) and BET data show that HEC-700 owns almost the same structure as $\mathrm{Co} / \mathrm{C}-700$, except the existence of Co element. The S@Co/C-700 and S@HEC-700 electrodes were prepared as the cathodes for Li-S batteries. As shown in Fig. S6, the main weight loss between room temperature and $450{ }^{\circ} \mathrm{C}$ is attributed to the sublimation of sulfur, corresponding to the sulfur content of $70.99 w t \%$ and $68.42 w t \%$ in S@Co/C-700 and S@HEC700 , respectively.
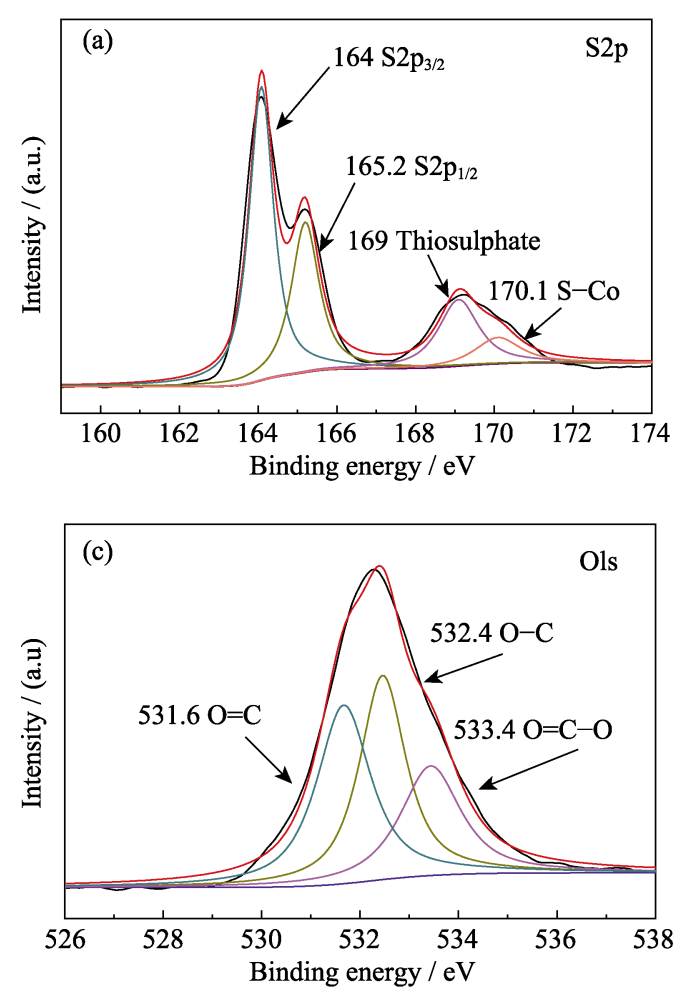

The surface composition of S@Co/C-700 was investigated by XPS. The survey spectrum (Fig. S7) shows the presence of $\mathrm{S}, \mathrm{C}, \mathrm{N}, \mathrm{O}$ and Co elements on the surface of the composite. The little $\mathrm{N}$ is from the precursor of $\mathrm{Co}\left(\mathrm{NO}_{3}\right)_{2}$. The extremely low ratio of sulfur $(7.83 \mathrm{at} \%)$ indicates that the sulfur crystal has successfully infiltrated into the porous structure. The highresolution spectrum of $\mathrm{S} 2 \mathrm{p}$ (Fig. 4(a)) shows four main peaks. The peaks at 164 and $165.2 \mathrm{eV}$ correspond to the $\mathrm{S} 2 \mathrm{p}_{3 / 2}$ and $\mathrm{S} 2 \mathrm{p}_{1 / 2}{ }^{[27]}$, respectively. The peaks located at 169 and $170.1 \mathrm{eV}$ are attributed to thiosulphate and S-Co, respectively. The $\mathrm{C} 1 \mathrm{~s}$ spectrum is presented in Fig. 4(b). The peaks at $284.8,285.6$ and $288.8 \mathrm{eV}$ correspond to $\mathrm{C}-\mathrm{C}, \mathrm{C}-\mathrm{O}$ and $\mathrm{O}=\mathrm{C}-\mathrm{O}$ bonds ${ }^{[28-29]}$, almost the same as the $\mathrm{C} 1 \mathrm{~s}$ spectrum of $\mathrm{Co} / \mathrm{C}-700$ (Fig. S8(a)). And the spectrum of $\mathrm{O} 1 \mathrm{~s}$ (Fig. 4(c)) shows the $\mathrm{O}=\mathrm{C}, \mathrm{O}-\mathrm{C}$ and $\mathrm{O}=$ $\mathrm{C}-\mathrm{O}$ at $531.6,532.4$ and $533.4 \mathrm{eV}$, respectively ${ }^{[30]}$. When compared with $\mathrm{Co} / \mathrm{C}-700$ (Fig. S8(b)), all these peaks shift more than $0.5 \mathrm{eV}$ and further verify the interaction between sulfur and oxygen functional groups. Moreover, the spectrum of Co2p at Fig. 4(d) shows two main peaks of $\mathrm{Co} 2 \mathrm{p}_{3 / 2}$ and $\mathrm{Co} 2 \mathrm{p}_{1 / 2}$ at 780.3 and $797.9 \mathrm{eV}^{[21]}$, which represent for the cobalt metal. Different from the curves of Co/C-700 (Fig. S8(c)), two extra peaks appear at 783.7 and $800.4 \mathrm{eV}$ in $\mathrm{S} @ \mathrm{Co} / \mathrm{C}-700$ which suggest the strong interaction between sulfur and cobalt. The static adsorption test was employed to investigate the interaction
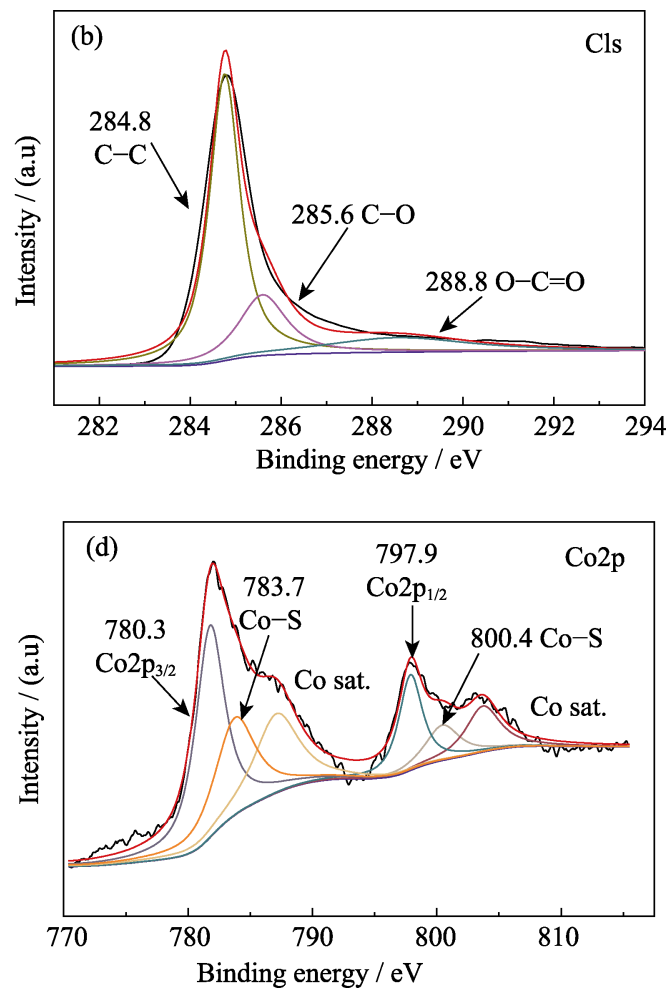

Fig. 4 High resolution XPS spectra for $\mathrm{S} @ \mathrm{Co} / \mathrm{C}-700$ composites (a) $\mathrm{S} 2 \mathrm{p}$; (b) $\mathrm{C} 1 \mathrm{~s}$; (c) $\mathrm{O} 1 \mathrm{~s}$; (d) Co2p 

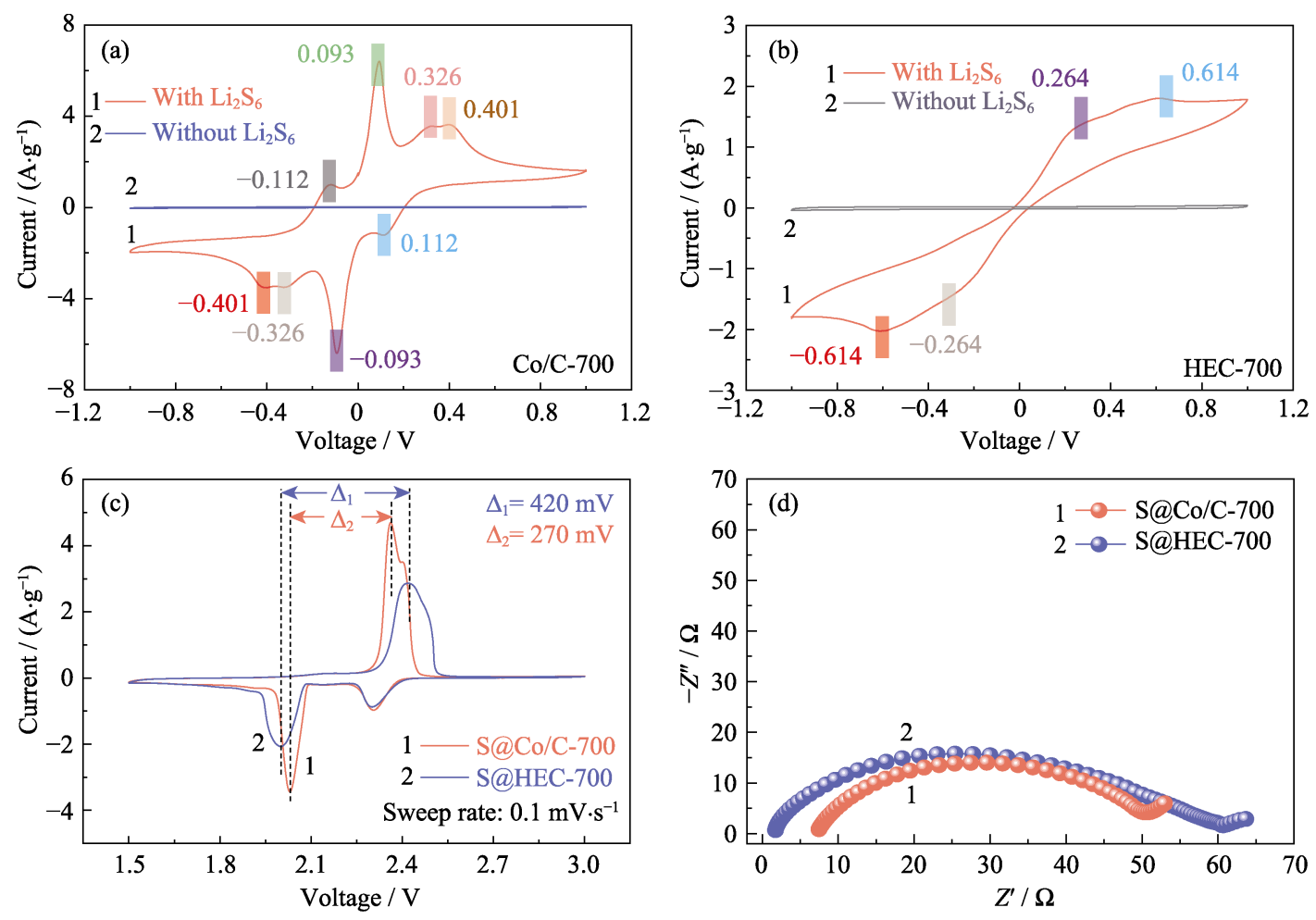

Fig. $5 \mathrm{CV}$ curves of (a) Co/C-700 and (b) HEC-700 based symmetric cells with and without $0.2 \mathrm{~mol} \cdot \mathrm{L}^{-1} \mathrm{Li}_{2} \mathrm{~S}_{6}$ at $1 \mathrm{mV} \cdot \mathrm{s}^{-1}$; (c) CV curves and (d) EIS plots of S@Co/C-700 and S@HEC-700 electrodes

between LiPSs and Co/C-700 or HEC-700 more intuitively. And the photograph reveals the colorless solution of $\mathrm{Co} / \mathrm{C}-700$ and the almost unchanged color of HEC700 (Fig. S9). The obvious difference of two samples further confirms that Co nanoparticles can effectively adsorb LiPSs on the surface and be ready for the further redox reactions ${ }^{[31]}$.

Apart from the effective adsorption and strong interaction, the doping cobalt nanoparticles can efficiently improve the kinetics of conversion reaction between $\mathrm{S}_{8}$ and $\mathrm{Li}_{2} \mathrm{~S}$. Cyclic voltammetry $(\mathrm{CV})$ of the symmetric cells with $\mathrm{Co} / \mathrm{C}-700$ and HEC-700 electrodes were used to confirm the effect of cobalt nanoparticles. The $\mathrm{CV}$ curves in Fig. 5(a) clearly reveal eight redox peaks with great superimposition (Fig. S10(a)). The separation and stability of the redox peaks indicate the improved reversibility and kinetics of the conversion reaction. In addition, the curve of the first scan to $-1 \mathrm{~V}$ reveals three peaks that represent the stepwise reduction from original $\mathrm{Li}_{2} \mathrm{~S}_{6}$ to insoluble $\mathrm{Li}_{2} \mathrm{~S}$ on the work electrode and oxidation of $\mathrm{Li}_{2} \mathrm{~S}_{6}$ on the counter electrode. The four peaks at $-0.112,0.093,0.326$ and $0.401 \mathrm{~V}$ represent the stepwise oxidation from $\mathrm{Li}_{2} \mathrm{~S}$ to element sulfur on the working electrode. Therefore, the peak at $0.112 \mathrm{~V}$ corresponds to the reduction from $\mathrm{S}_{8}$ to $\mathrm{Li}_{2} \mathrm{~S}_{6}$. In addition, the peaks with good sustainability under higher scan rates (Fig. S10(b)) also indicate the efficient electrochemical process based on the $\mathrm{Co} / \mathrm{C}-700$ electrodes. In con- trast, the experimental control of HEC-700 electrodes show only two pairs of broad peaks (Fig. 5(b)) with the cyclic drifting (Fig. S10(c)), and the inconspicuous peaks at $-0.264 / 0.264 \mathrm{~V}$ become invisible under higher rates (Fig. S10(d)), indicating the sluggish kinetics and incomplete conversion of the polysulfides reaction without the existence of Co nanoparticles.

To further confirm the enhanced electrochemical kinetics in the presence of cobalt nanoparticles, the $\mathrm{CV}$ tests of $\mathrm{S} @ \mathrm{Co} / \mathrm{C}-700$ and S@HEC-700 electrodes (Fig. 5(c)) were measured at a scan rate of $0.1 \mathrm{mV} \cdot \mathrm{s}^{-1}$. For the cathodic reduction process of $\mathrm{S} @ \mathrm{Co} / \mathrm{C}-700$, two reversible peaks at 2.306 and $2.031 \mathrm{~V}$ are associated with the transformation from sulfur to soluble LiPSs and further reduction to insoluble $\mathrm{Li}_{2} \mathrm{~S}_{2} / \mathrm{Li}_{2} \mathrm{~S}$, respectively. In comparation, the latter reduction peak of S@HEC-700 shows a significant negative shift. It suggests the more sluggish reaction kinetics, which may increase the detention time of LiPSs and aggravate the shuttling effect. For the anodic process, the oxidation process of S@Co/C-700 reveals an unobtrusive peak at $2.397 \mathrm{~V}$ and a major peak at $2.361 \mathrm{~V}$, corresponding to the oxidation from $\mathrm{Li}_{2} \mathrm{~S}_{2} / \mathrm{Li}_{2} \mathrm{~S}$ to LiPSs and further to sulfur, respectively. The separation of the oxidation peaks shows the enhanced kinetics of the former reaction. Furthermore, the interval between the second reduction peak and the major oxidation peak of S@Co/C-700 (270 mV, Fig. 5(c)) is significantly smaller than that of S@HEC-700 (420 mV), 
indicating the reduced polarization overpotential and improved kinetics of redox reaction with the existence of cobalt. The EIS curves (Fig. 5(d)) show smaller chargetransfer resistance (the size of high-frequency semicircle) of $\mathrm{S} @ \mathrm{Co} / \mathrm{C}-700$ electrode $(43.1 \Omega)$ than that of $\mathrm{S} @$ HEC-700 (58.7 $\Omega$ ), which also reveals the enhanced reaction kinetics by cobalt.

Fig. 6 compares the electrochemical performance of the S@Co/C-700 and S@HEC-700 cathodes. The rate capabilities of S@Co/C-700 (Fig. 6(a)) show a much higher initial discharge capacity $\left(1280 \mathrm{mAh} \cdot \mathrm{g}^{-1}\right)$ than $\mathrm{S} @$ HEC-700 (847 $\left.\mathrm{mAh} \cdot \mathrm{g}^{-1}\right)$ at the current rate of $0.5 \mathrm{C}$ $\left(1 C=1672 \mathrm{mAh} \cdot \mathrm{g}^{-1}\right)$. At higher cycling rates of $1 C, 2 C$, $5 C$ and $10 C$, the discharge capacities of $\mathrm{S} @ \mathrm{Co} / \mathrm{C}-700$ cathode reach 1058, 948, 867 and $797 \mathrm{mAh} \cdot \mathrm{g}^{-1}$, and further recover to $968 \mathrm{mAh} \cdot \mathrm{g}^{-1}$ at $1 C(95 \%$ of the 10 th cycle). And the galvanostatic charge-discharge voltage profiles at different rates show that the S@Co/C-700 electrode exerts smaller overpotential and much longer discharge plateau even at $10 C$ (Fig. S11). The cycle stabilities of the two cathodes at $1 C$ rate are compared in Fig. 6(b). The S@Co/C-700 cathode shows a high initial capacity of $1244 \mathrm{mAh} \cdot \mathrm{g}^{-1}$, and maintains $770 \mathrm{mAh} \cdot \mathrm{g}^{-1}$ after 200 cycles with high Coulomb efficiency (higher than $96 \%$ ), revealing much higher capacity and better stability than the S@HEC-700. The long-term cycling performances at $2 C$ exhibited in Fig. S12(a). After 600
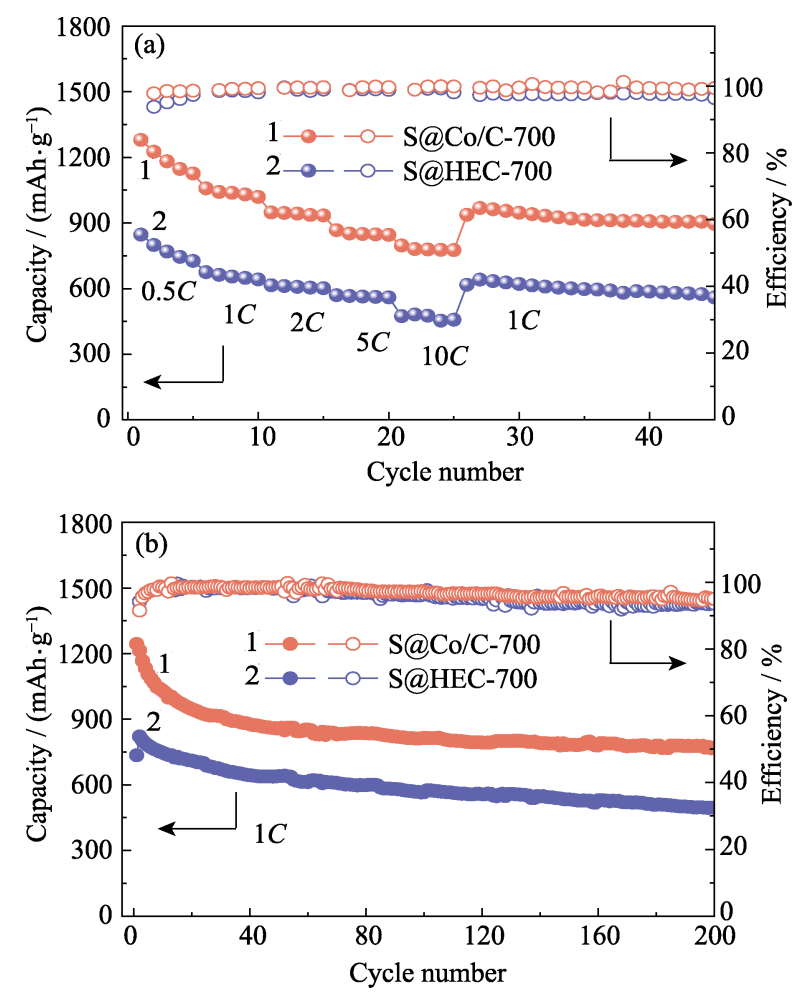

Fig. 6 (a) Rate capabilities at various rates from $0.5 C$ to $10 C$ and (b) cycling stabilities at $1 C$ for $\mathrm{S} @ \mathrm{Co} / \mathrm{C}-700$ and S@HEC-700 electrodes cycles, the S@Co/C-700 cathode maintained a discharge capacity of $401.7 \quad \mathrm{mAh} \cdot \mathrm{g}^{-1} \quad\left(65.3 \mathrm{mAh} \cdot \mathrm{g}^{-1}\right.$ for $\mathrm{S} @$ HEC-700). The extremely high rates at $5 C$ and $10 C$ are further evaluated for the $\mathrm{S} @ \mathrm{Co} / \mathrm{C}-700$ cathode (Fig. S12(b)). It shows high initial discharge capacities (1098 and $772 \mathrm{mAh} \cdot \mathrm{g}^{-1}$ at $5 C$ and $10 C$, respectively) without any activation step and stable cycling performance (518 and $416 \mathrm{mAh} \cdot \mathrm{g}^{-1}$ at $5 C$ and $10 C$, respectively) for more than 200 cycles. The more excellent cycle stability and rate performance of $\mathrm{S} @ \mathrm{Co} / \mathrm{C}-700$ electrode is attributted to the benefits of cobalt nanoparticles.

\section{Conclusion}

In summary, we design a large-scale synthesis of $\mathrm{Co} / \mathrm{C}-700$ composites as the host material to support sulfur for Li-S batteries. Combining with the results of $\mathrm{CV}$ and EIS, we conclude that the embedded Co nanoparticles decrease the overpotential and promote the conversion kinetics of LiPSs. Furthermore, the XPS and static adsorption test show the strong interaction between LiPSs and the doped Co. With the cooperation of $\mathrm{Co}$ and the unique hollow porous structure, the obtained S@Co/C-700 cathodes exhibit high specific capacity of $1280 \mathrm{mAh} \cdot \mathrm{g}^{-1}$ at $0.5 C$, and stable long cycle performance from $1 C$ to $10 C$. This work demonstrates the feasibility of high energy density Li-S batteries with the dopant of cobalt metal for high-rate requirements.

\section{Supporting materials}

Supporting materials related to this article can be found at https://doi.org/10.15541/jim20200161.

\section{Reference:}

[1] YE C, ZHANG L, GUO C X, et al. A 3D hybrid of chemically coupled nickel sulfide and hollow carbon spheres for high performance lithium-sulfur batteries. Advanced Functional Materials, 2017, 27(33): 1702524-1-9.

[2] YIN Y X, XIN S, GUO Y G, et al. Lithium-sulfur batteries: electrochemistry, materials, and prospects. Angewandte Chemie International Edition, 2013, 52(50): 13186-13200.

[3] HU T C, PANG Y, WANG Y G, et al. $\mathrm{S}_{0.87} \mathrm{Se}_{0.13} /$ CPAN composites as high capacity and stable cycling performance cathode for lithium sulfur battery. Electrochimica Acta, 2018, 281: 789-795.

[4] CHEN Z Y, ZHOU J J, GUO Y S, et al. A compatible carbonate electrolyte with lithium anode for high performance lithium sulfur battery. Electrochimica Acta, 2018, 282: 555-562.

[5] LI C B, YUE H Y, WANG Q X, et al. A novel modified PP separator by grafting PAN for high-performance lithium-sulfur batteries. Journal of Materials Science, 2019, 54(2): 1566-1579.

[6] HUANG S Z, ZHANG L L, WANG J Y, et al. In situ carbon nanotube clusters grown from three-dimensional porous graphene networks as efficient sulfur hosts for high-rate ultra-stable Li-S batteries. Nano Research, 2018, 11(3): 1731-1743. 
[7] CHABU J M, ZENG K, CHEN W S, et al. A novel graphene oxide-wrapped sulfur composites cathode with ultra-high sulfur content for lithium-sulfur battery. Applied Surface Science, 2019, 493: 533-540.

[8] JIN S, XIN S, WANG L J, et al. Covalently connected carbon nanostructures for current collectors in both the cathode and anode of Li-S batteries. Advanced Materials, 2016, 28(41): 9094-9102.

[9] ZHANG S S. Heteroatom-doped carbons: synthesis, chemistry and application in lithium/sulphur batteries. Inorganic Chemistry Frontiers, 2015, 2(12): 1059-1069.

[10] YANG S T, YAN C, CAO Z X, et al. Preparation of hierarchical porous carbon/sulfur composite based on lotus-leaves and its property for Li-S batteries. Journal of Inorganic Materials, 2016, 31(2): 135.

[11] PANG Q, KUNDU D, CUISINIER M, et al. Surface-enhanced redox chemistry of polysulphides on a metallic and polar host for lithium-sulphur batteries. Nature Communications, 2014, 5: 4759-1-8.

[12] ZHANG H, ZOU M C, ZHAO W Q, et al. Highly dispersed catalytic $\mathrm{Co}_{3} \mathrm{~S}_{4}$ among a hierarchical carbon nanostructure for high-rate and long-life lithium-sulfur batteries. ACS Nano, 2019, 13(4): 3982-3991.

[13] LIN H B, YANG L Q, JIANG X, et al. Electrocatalysis of polysulfide conversion by sulfur-deficient $\mathrm{MoS}_{2}$ nanoflakes for lithium-sulfur batteries. Energy \& Environmental Science, 2017, 10(6): 1476-1486.

[14] LI S P, CHEN X, HU F, et al. Cobalt-embedded carbon nanofiber as electrocatalyst for polysulfide redox reaction in lithium sulfur batteries. Electrochimica Acta, 2019, 304: 11-19.

[15] LIU Z Z, ZHOU L, GE Q, et al. Atomic iron catalysis of polysulfide conversion in lithium-sulfur batteries. ACS Applied Materials \& Interfaces, 2018, 10(23): 19311-19317.

[16] AL SALEM H, BABU G, RAO C V, et al. Electrocatalytic polysulfide traps for controlling redox shuttle process of Li-S batteries. Journal of the American Chemical Society, 2015, 137(36): $11542-11545$.

[17] LIM W G, KIM S, JO C S, et al. A comprehensive review of materials with catalytic effects in Li-S batteries: enhanced redox kinetics. Angewandte Chemie International Edition, 2019, 58(52): 18746-18757.

[18] LUO S Q, ZHENG C M, SUN W W, et al. Controllable preparation of Co-NC nanoporous carbon derived from ZIF-67 for advanced lithium-sulfur batteries. Journal of Inorganic Materials, 2019, 34(5): 45-51.

[19] LI Y J, FAN J M, ZHENG M S, et al. A novel synergistic composite with multi-functional effects for high-performance Li-S batteries. Energy \& Environmental Science, 2016, 9(6): 1998-2004.

[20] DU Z Z, CHEN X J, HU W, et al. Cobalt in nitrogen-doped graphene as single-atom catalyst for high-sulfur content lithiumsulfur batteries. Journal of the American Chemical Society, 2019, 141(9): 3977-3985.

[21] WU Q P, ZHOU X J, XU J, et al. Adenine derivative host with interlaced 2D structure and dual lithiophilic-sulfiphilic sites to enable high-loading Li-S batteries. ACS Nano, 2019, 13(8): 9520-9532.

[22] YANG B J, CHEN J T, LEI S L, et al. Spontaneous growth of 3D framework carbon from sodium citrate for high energy- and power-density and long-life sodium-ion hybrid capacitors. Advanced Energy Materials, 2018, 8(10): 1702409-1-11.

[23] ADDOUN A, DENTZER J, EHRBURGER P. Porosity of carbons obtained by chemical activation: effect of the nature of the alkaline carbonates. Carbon, 2002, 40(7): 1140-1143.

[24] SHI C C, YANG X L, ZHANG L L, et al. High-performance $\mathrm{SiO} / \mathrm{C} / \mathrm{G}$ composite anode for lithium ion batteries. Journal of Inorganic Materials, 2013, 28(9): 943-948.

[25] TANG F Y, WANG L Q, LIU Y N. Biomass-derived N-doped porous carbon: an efficient metal-free catalyst for methylation of amines with $\mathrm{CO}_{2}$. Green Chemistry, 2019, 21(23): 6252-6257.

[26] MA L B, LIN H N, ZHANG W J, et al. Nitrogen-doped carbon nanotube forests planted on cobalt nanoflowers as polysulfide mediator for ultralow self-discharge and high areal-capacity lithium-sulfur batteries. Nano Letters, 2018, 18(12): 7949-7954.

[27] LI Z Q, LI C X, GE X L, et al. Reduced graphene oxide wrapped MOFs-derived cobalt-doped porous carbon polyhedrons as sulfur immobilizers as cathodes for high performance lithium sulfur batteries. Nano Energy, 2016, 23: 15-26.

[28] SU D W, CORTIE M, WANG G X. Fabrication of N-doped graphene-carbon nanotube hybrids from prussian blue for lithium-sulfur batteries. Advanced Energy Materials, 2017, 7(8): 1602014-1-12.

[29] ZHANG Y Q, MA D K, ZHUANG Y, et al. One-pot synthesis of $\mathrm{N}$-doped carbon dots with tunable luminescence properties. Journal of Materials Chemistry, 2012, 22(33): 16714-16718.

[30] TANG F Y, WANG L Q, DESSIE WALLE M, et al. An alloy chemistry strategy to tailoring the d-band center of $\mathrm{Ni}$ by $\mathrm{Cu}$ for efficient and selective catalytic hydrogenation of furfural. Journal of Catalysis, 2020, 383: 172-180

[31] FAN C Y, LIU S Y, LI H H, et al. Synergistic mediation of sulfur conversion in lithium-sulfur batteries by a Gerber tree-like interlayer with multiple components. Journal of Materials Chemistry A, 2017, 5(22): 11255-11262

\title{
锂硫电池正极用钴掺杂空心多孔碳载体材料
}

\author{
金高尧，何海传，吴杰，张梦源，李亚娟，刘又年 \\ (中南大学 化学化工学院, 湖南省微纳材料界面科学重点实验室, 长沙 410083)
}

\begin{abstract}
摘 要: 锂硫电池被认为是新一代低成本、高能量密度的储能系统。但由于硫正极导电性差、穿梭效应严重以及氧 化还原反应速率慢, 导致电池容量衰减严重, 倍率性能较差。本研究以柠檬酸钠为碳源制备了具有三维中空结构的 多孔碳材料, 并在其骨架上负载钴纳米颗粒后作为硫正极的载体。引入的钻纳米颗粒可有效吸附多硫化物, 提升其 转化反应的动力学, 进而明显改善电池的循环和倍率性能。所得的钴掺杂复合硫正极在 $0.5 C\left(1 C=1672 \mathrm{mAh} \cdot \mathrm{g}^{-1}\right)$ 的 倍率下首圈放电比容量高达 $1280 \mathrm{mAh} \cdot \mathrm{g}^{-1}$, 在 $1 C$ 的倍率下稳定循环 200 圈后可保持 $770 \mathrm{mAh} \cdot \mathrm{g}^{-1}$, 并且具有优异的 倍率性能, 即使在 $10 C$ 的大电流密度下仍可稳定循环。
\end{abstract}

关 键 词: 锂硫电池; 钴纳米颗粒; 转化反应; 硫正极

中图分类号: TM912 文献标识码: A 
Supporting information:

\title{
Cobalt-doped Hollow Carbon Framework as Sulfur Host for the Cathode of Lithium Sulfur Battery
}

\author{
JIN Gaoyao, HE Haichuan, WU Jie, ZHANG Mengyuan, LI Yajuan, LIU Younian
}

(Hunan Provincial Key Laboratory of Micro \& Nano Materials Interface Science, College of Chemistry and Chemical Engineering, Central South University, Changsha 410083, China)

\section{Materials characterization}

The crystalline structures of the as-synthesized samples were characterized by X-ray power diffraction (XRD, Dmax/2550VB, Rigaku, Japan) with $\mathrm{Cu} \mathrm{K \alpha}$ radiation. The surface morphology and microstructure were obtained by a scanning electron microscopy (SEM, FEI Verios 460). Transmission electron microscopy (TEM, JEM-2100F) equipped with an X-ray energy dispersive spectrometer (EDS) was used to collect transmission and high-resolution images of the $\mathrm{Co} / \mathrm{C}-700$. The Co content in Co/C-700 and S content in S@Co/C700 or S@HEC-700 were determined by thermogravimetric analyzer (TGA, Q600, USA) in air or $\mathrm{N}_{2}$, respectively, with a heating rate of $10{ }^{\circ} \mathrm{C} \cdot \mathrm{min}^{-1}$. Raman spectroscopy was performed using a reflex Raman system (Renishaw in Via Raman microscope, UK) equipped with a microscope under $532 \mathrm{~nm}$ laser radiation at $50 \mathrm{~mW}$. X-ray photoelectron spectrometer (XPS) analysis was performed at an ESCALAB 250XI X-ray photoelectron spectrometer (Thermo Fisher Scientific, USA). The specific surface area and pore size distribution of samples were determined by nitrogen adsorptiondesorption analysis.

\section{Static adsorption of polysulfides}

Typically, $0.003 \mathrm{~mol} / \mathrm{L} \mathrm{Li}_{2} \mathrm{~S}_{6}$ solution was obtained by reacting stoichiometric $\mathrm{Li}_{2} \mathrm{~S}$ and $\mathrm{S}$ in 1,2-dimethoxyethane(DME) and 1,3-dioxolane(DOL) (1:1 in volume) at $60{ }^{\circ} \mathrm{C}$ for $24 \mathrm{~h}$. Then, $10 \mathrm{mg} \mathrm{Co} / \mathrm{C}-700$ or HEC-700 was added into $3 \mathrm{~mL}$ of the lithium polysulfide solution. The photograph was taken after the sample stood for $1 \mathrm{~h}$.

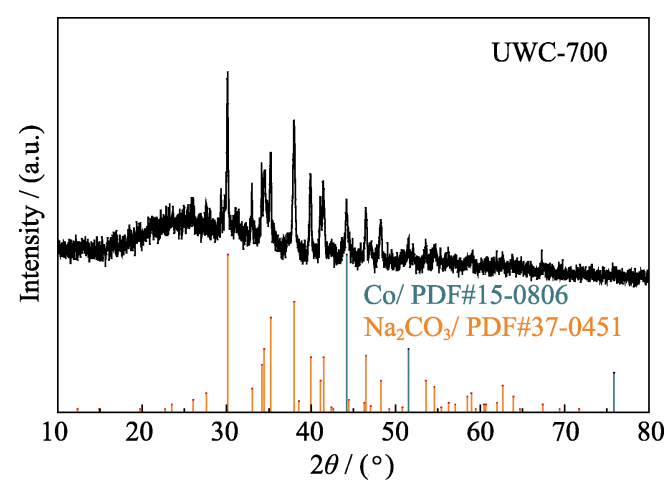

Fig. S1 XRD pattern of UWC-700
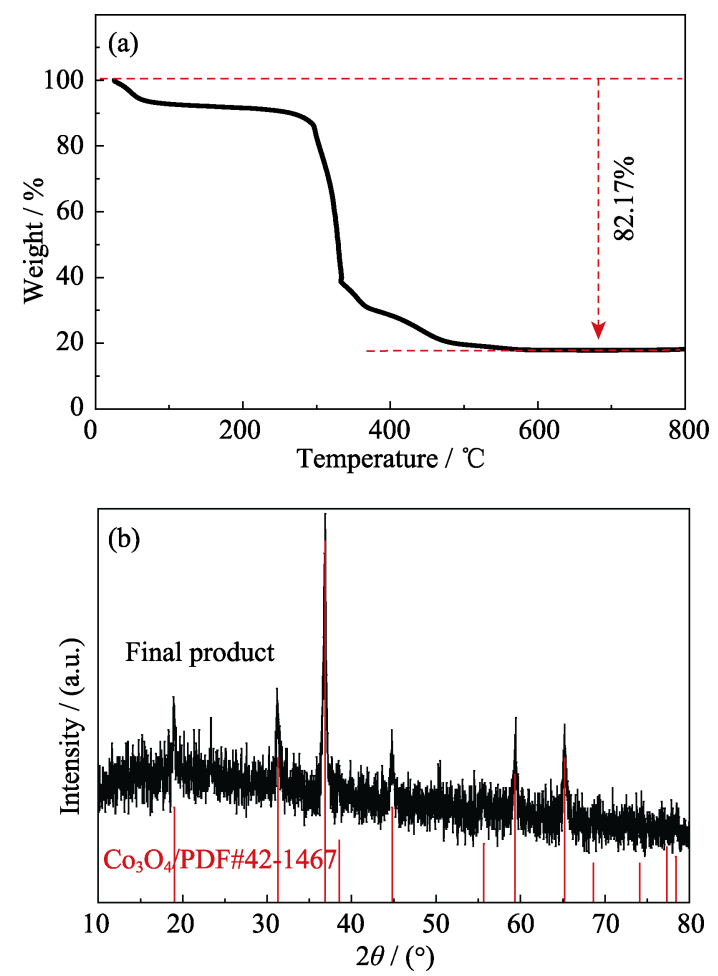

Fig. S2 (a) TGA curve of $\mathrm{Co} / \mathrm{C}-700$ in air and (b) XRD pattern of the final product

Table S1 BET surface area and pore volume distribution of UWC-700, Co/C-700 and HEC-700

\begin{tabular}{cccrcc}
\hline Sample & \multirow{2}{*}{$S_{\mathrm{BET}} /\left(\mathrm{m}^{2} \cdot \mathrm{g}^{-1}\right)$} & $V_{\text {total }} /\left(\mathrm{cm}^{3} \cdot \mathrm{g}^{-1}\right)$ & \multicolumn{3}{c}{ Pore volume $/ \%$} \\
\cline { 4 - 6 } & 15.09 & 0.026 & Micro & Meso & Macro \\
\hline UWC-700 & 376.13 & 0.52 & 28.85 & 98.24 & 0 \\
HEC-700 & 369.53 & 0.54 & 25.47 & 62.76 & 8.49 \\
\hline
\end{tabular}



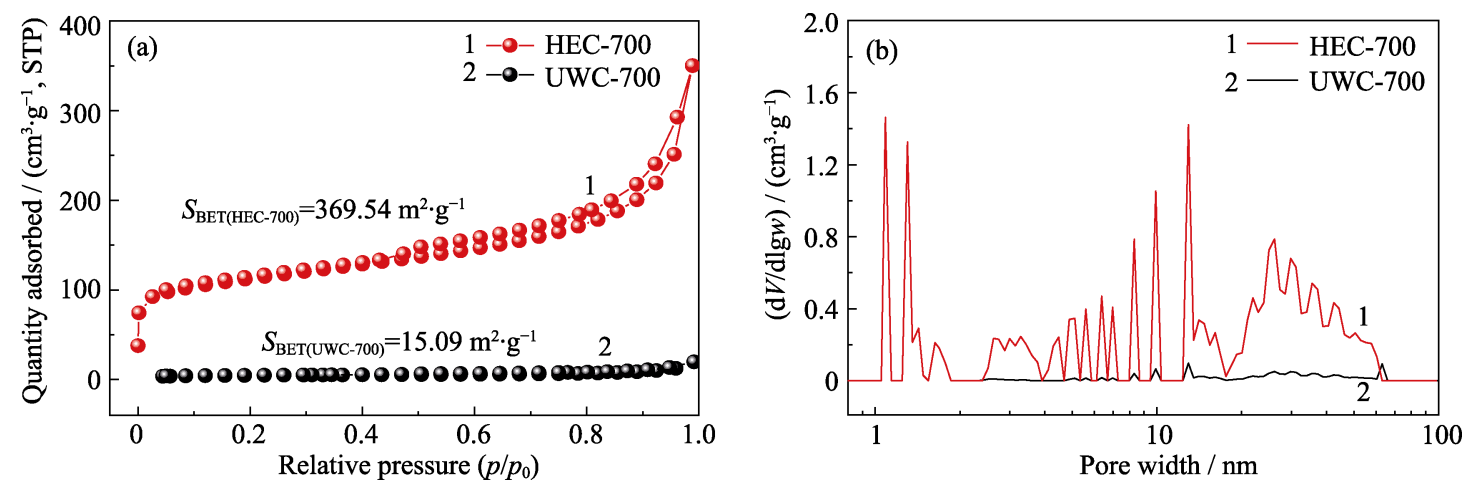

Fig. S3 $\mathrm{N}_{2}$ adsorption/desorption isotherms (a) and pore size distributions (b) of UWC-700 and HEC-700

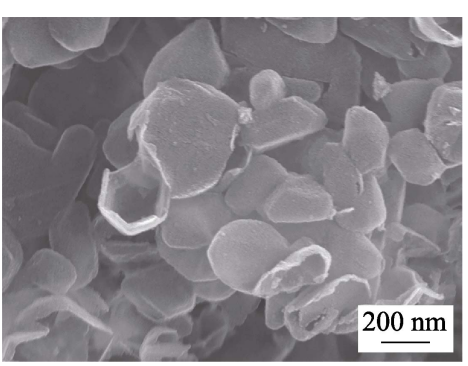

Fig. S4 SEM image of $\mathrm{Co} / \mathrm{C}-700$
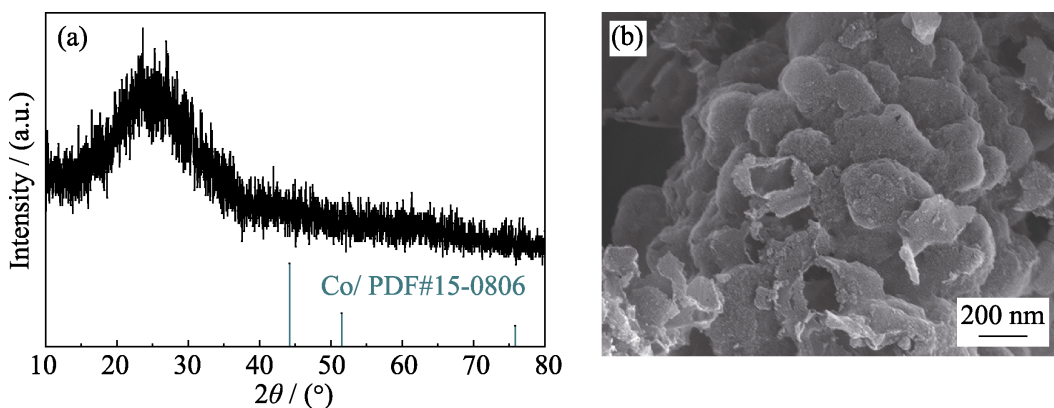

Fig. S5 XRD pattern (a) and SEM image (b) of HEC-700

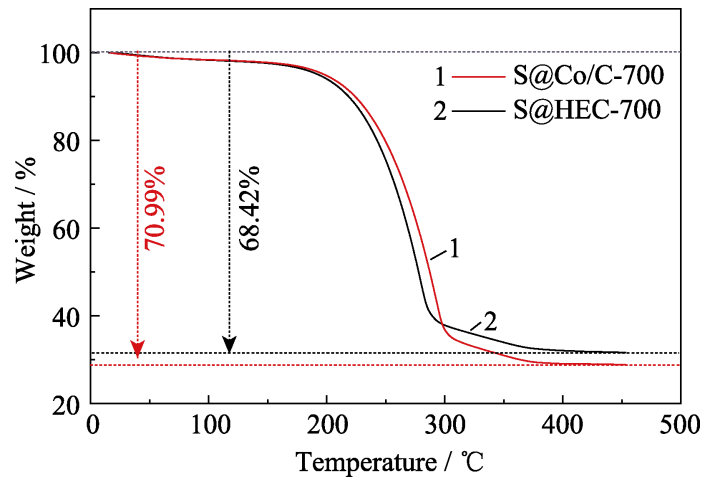

Fig. S6 TGA curves of S@Co/C-700 and S@HEC-700 under $\mathrm{N}_{2}$ atmosphere

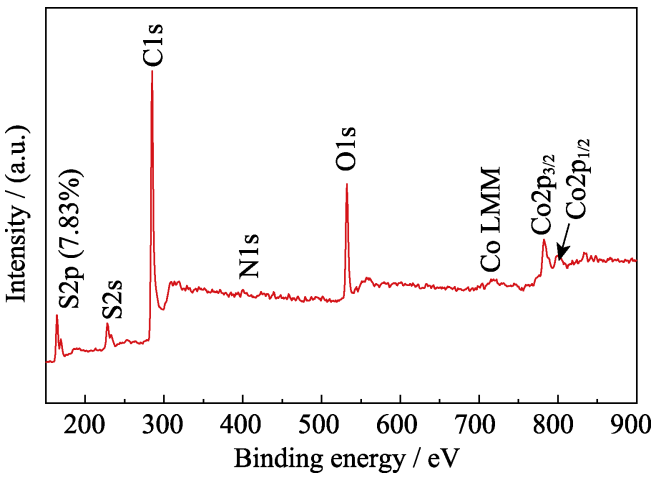

Fig. S7 XPS spectrum of S@Co/C-700 composite
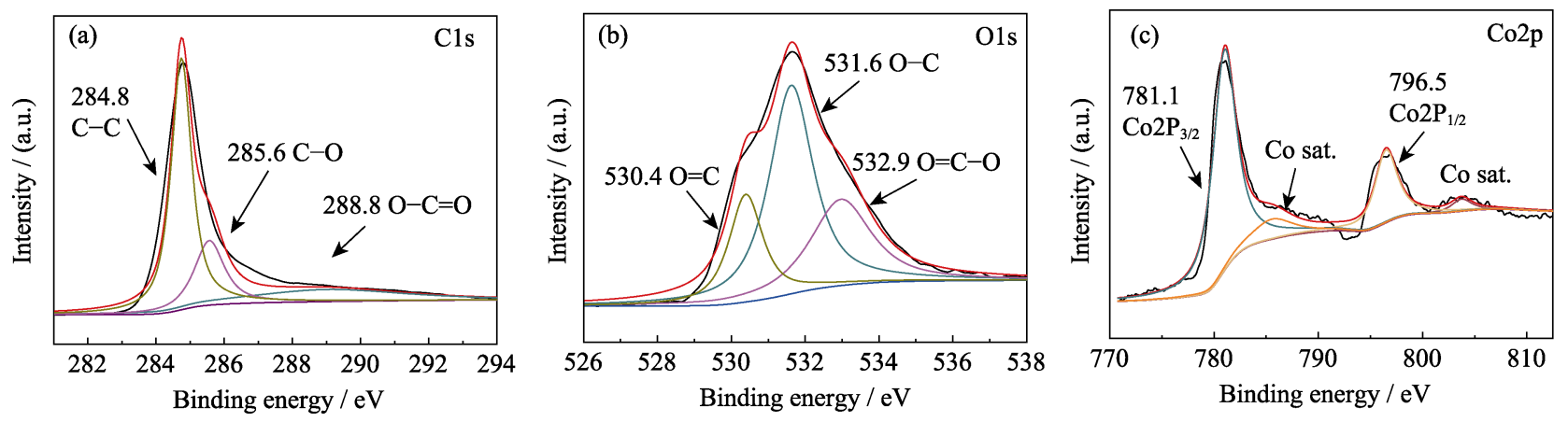

Fig. S8 High resolution XPS spectra of $\mathrm{Co} / \mathrm{C}-700$

(a) $\mathrm{C} 1 \mathrm{~s}$; (b) $\mathrm{O} 1 \mathrm{~s}$; (c) $\mathrm{Co} 2 \mathrm{p}$ 


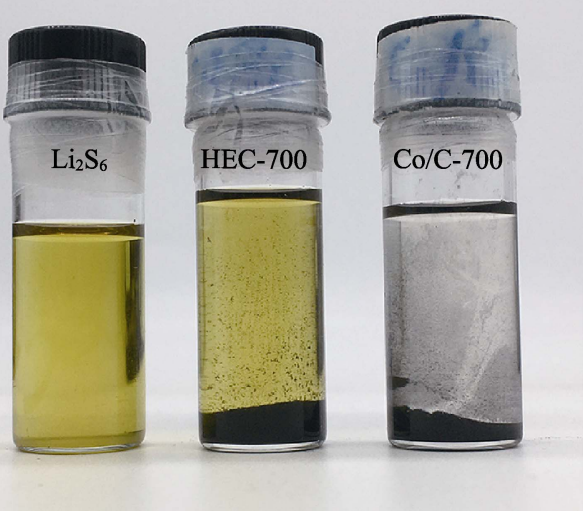

Fig. S9 Photograph of static adsorption test of HEC-700 and Co/C-700 after standing for $1 \mathrm{~h}$
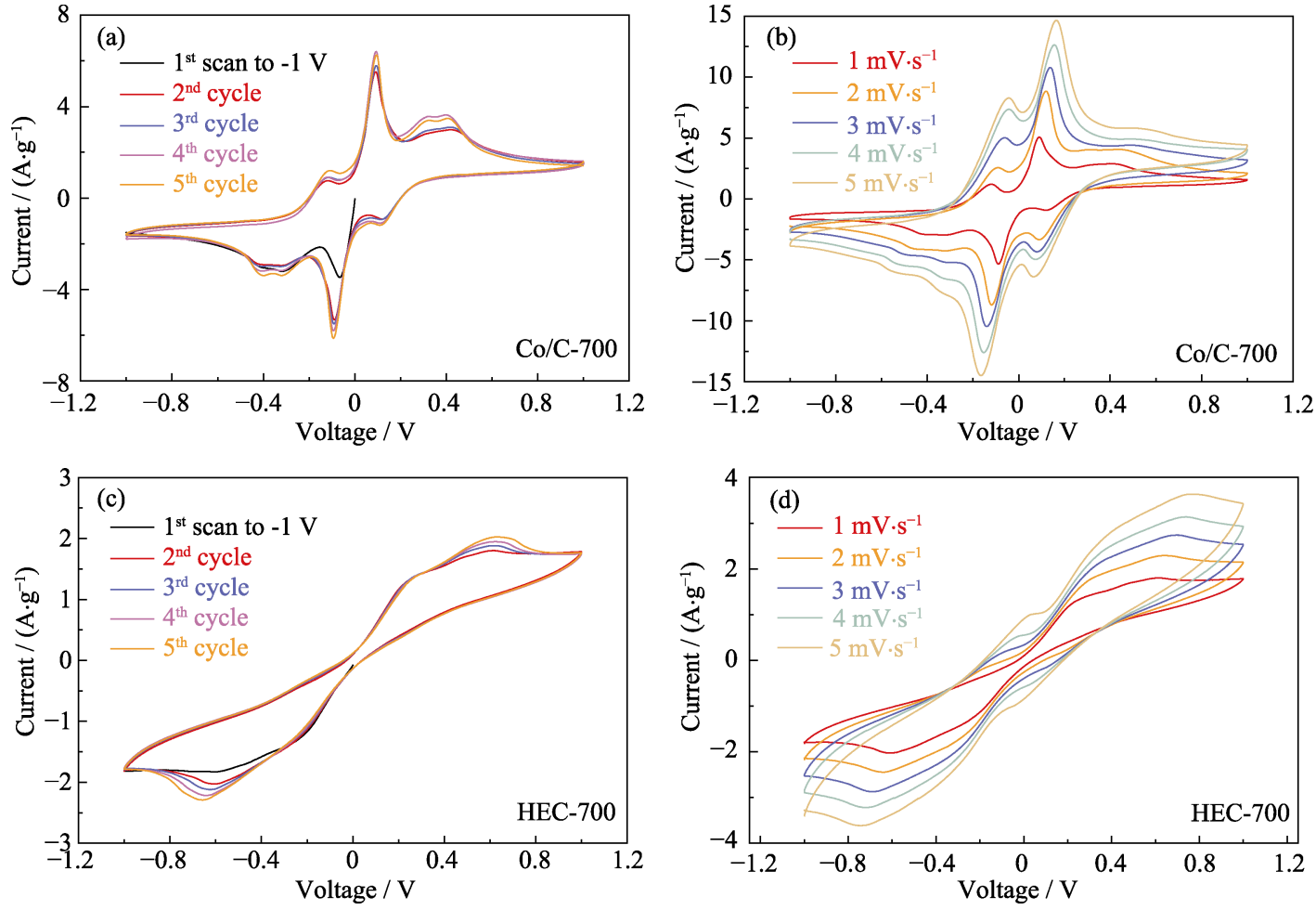

Fig. S10 Multi-cycle CV curves of Co/C-700 based symmetric cells at $1 \mathrm{mV} \cdot \mathrm{s}^{-1}$ (a) and increased rates (b), and multi-cycle CV curves of HEC-700 at $1 \mathrm{mV} \cdot \mathrm{s}^{-1}$ (c) and increased rates (d)
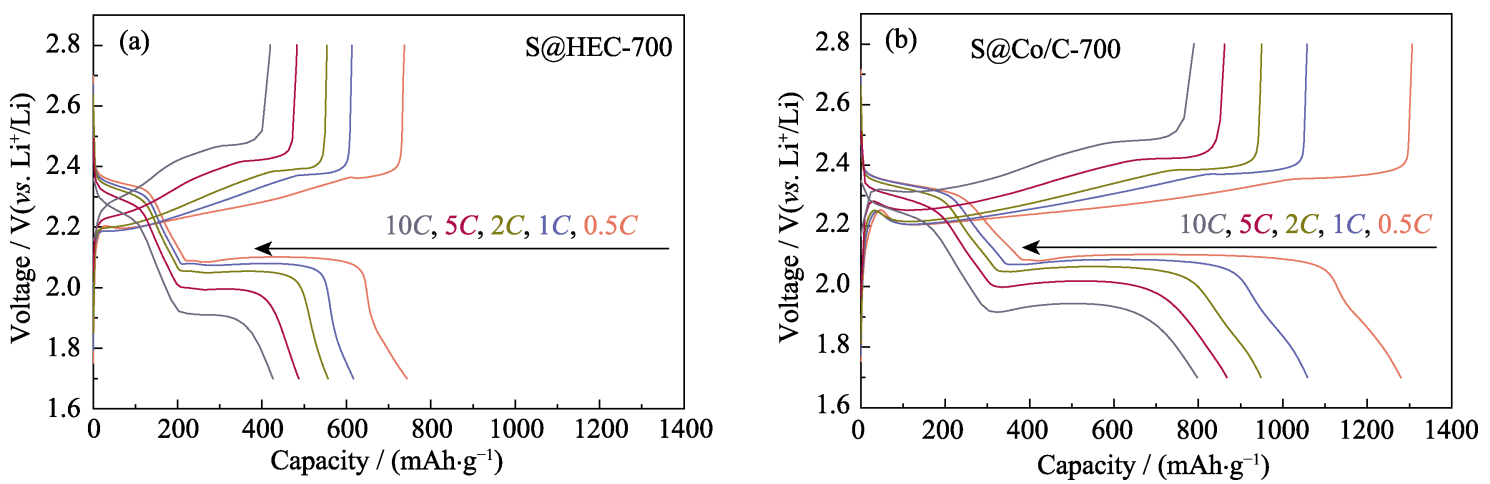

Fig. S11 Voltage profiles of S@HEC-700 (a) and S@Co/C-700 (b) electrodes at various rates from $0.5 C$ to $10 C$ 

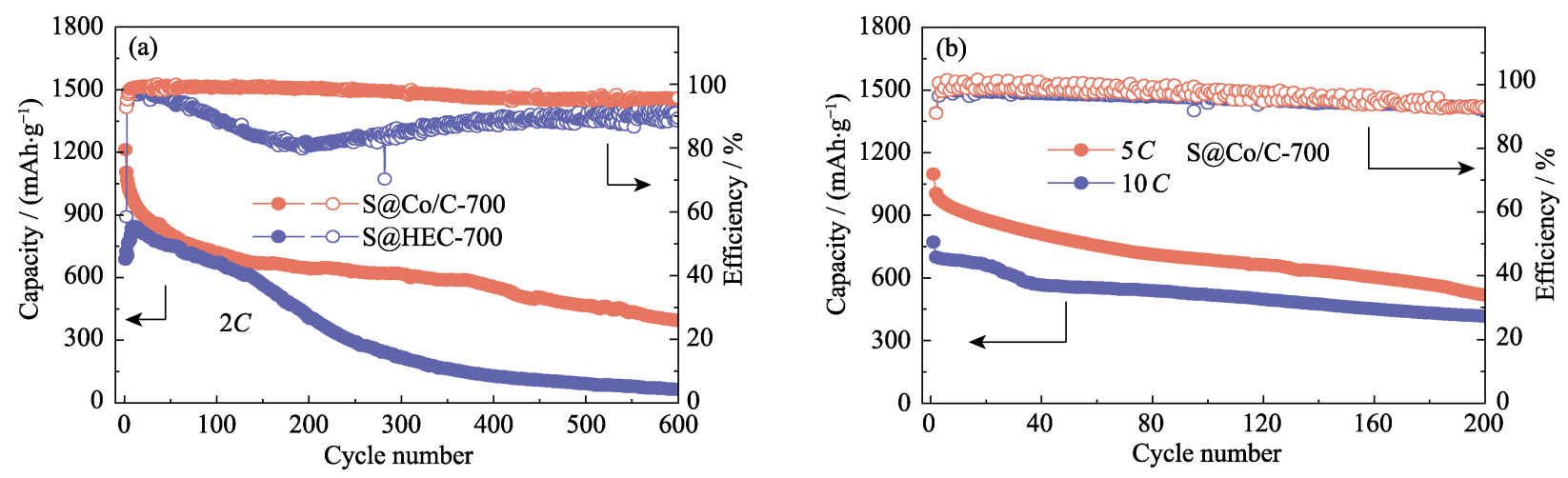

Fig. S12 (a) Cycling stabilities of S@Co/C-700 and S@HEC-700 electrodes at 2C;

(b) Cycling performance of $\mathrm{S} @ \mathrm{Co} / \mathrm{C}-700$ at $5 \mathrm{C}$ and $10 \mathrm{C}$ 